読者の広場 2

\section{平成元年度環境科学部会・光源部会 合同シンポジウム報告}

最近, 地球規模の環境問題が盛んに議論されている. そのよらな状況に対応して，11月 21 日国立教育会館に 牤いて「地球環境を診断する最近のスペクトロスコピ 一」と題するシンポジウムが開催された，講演は大気に 関するもの 4 件，水圈に関するもの 2 件であり，演者は いずれもこの分野で先駆的な研究者としてよく知られた 方々である。

始めに, 東大理学部小川利紘氏が「地球環境計測にお けるスペクトロコピー」と題して，大気環境を計測する 種々の分光学的手法について総括的に話をされた. 大気 分光測定の歴史は UV, IR を利用した太陽の吸收スペ クトルの観測に始まる。大気に関する測定対象は，污染 気体, 温室効果気体, 成層圈オゾン関連気体, エアロゾ ルなどの成分密度と大気全量，高度分布があり，さらに 気温, 風の情報子必要とされる.これらの測定に分光学 的手法を用いる場合その波長域は紫外からミリ波に旦 り，道具だてとしてフィルタ，回折格子，干渉計，レー ザーなどがある：又，観測方式が吸光か発光か，受動的 か能動的か，遠隔測定か直接測定か，によって測定法は 分類されるという. 演者はさらに吸光法と発光法の応用 例も示された．前者に関しては，ドブソン法によるオン゙ ソの観測，成層圈での $\mathrm{NO}_{2}$ の測定, 分解能 $0.1 \mathrm{~cm}^{-1}$ 程度の回折格子分光器による $\mathrm{HCl}$ の測定などにるれら れた，後者の発光法については気球による $\mathrm{H}_{2} \mathrm{O}, \mathrm{CO}_{2}$, $\mathrm{HNO}_{3}$ などの観測，遠赤外域の発光分子などが紹介され た. 講演の焦点は分光測定に絞られていたが，その中で 温室効果の要因やオン゙ン層の消隇反応といら現在最も関 心を集めている話題にも言及され, 今回のシンポジウム 主題にふさわしい講演内容であった.

続いて国立公害研究所の中根英昭氏が「紫外吸収を利 用した成層圏のオゾンの遠隔計測」について講演され た.オゾンは太陽紫外線の吸収源であるとともに成層圏 の主な熱源として大気の循環を支配している. 現在のと ころ，南極ではフロンに起因するオゾン濃度の減少が, 北極ではオゾンホール存在の可能性が認識されている が，高度分布のトレンドに関してははっきりした結論が 得られていない.オゾン破壊のメカニズム解明のために も, 高精度な地上からの観測が重要となる. 地上からの 観測法の中で，演者は特にレーザーレーダーをとりあげ
て原理と解析方法を説明された. 2 波長の光の吸収係数 の差を利用する差分吸収レーザーレーダー (Differential Absorption LIDAR: DIAL) を用いるとオン゙ン濃度の 高度分布を得ることがでさる．DIAL は，エアロゾルが 汪とんど存在しない高度領域では較正の必要がなく，絶 対測定が可能な観測装置である。な特，光源として用い るレーザーは高度によって最適波長のものを選択する必 要がある，例えば成層圈オゾンの測定には，オゾンによ る吸収の大さい波長で発振する XeCl レーザー(308 nm), 吸収の小さい波長用としてXeF レーザーや YAG レー ザーの第 3 高調波 $(351 \mathrm{~nm})$ などを利用する．国立公害 研究所の成層圏オゾン測定用レーザーレーダーは, 光源

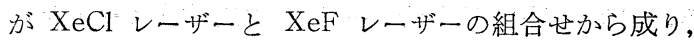
多波長を用いることによってエアロゾルの影響を補正し

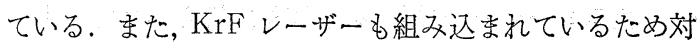
流圏のオゾンも観測することができる. 終りに測定上の 注意事項を総括され，高度 $20 \mathrm{~km} \sim 40 \mathrm{~km}$ のそれぞれ の領域でオゾン濃度の季節変動が異なるといら現象を紹 介された.

気象研究所物理気象研究部に所属する牧野行雄氏の講 演は「赤外吸収を利用した大気中微量成分の測定」と題 するもので, 測定対象はオゾン, $\mathrm{CO}_{2}, \mathrm{CH}_{4}$, 水蒸気, $\mathrm{N}_{2} \mathrm{O}$ などである. 演者は第 24 次南極地域観測に隊員と して参加して和り，そこで実施された大気の吸収スペク トル測定の結果が本講演の中心となっている．序論では 吸収法の特徴を説明されたＦT-IR を用いることによ り高分解能を得られるが，高度分解能の点でレーダーよ り劣る。また，データーベースの充実が長所となる反 面，その不確かさが短所となることも指摘された. 1977 年〜1981年に行った観測は航空機に搭載した分光器によ るものであり，その分解能は $0.5 \mathrm{~cm}^{-1}$ にすぎなかった。 1983年〜89年に行われた昭和基地での観測には, FT-IR を太陽追尾装置と組合わせて使用している．室温で動作 する検出器の応答速度が遅かったため, 多数回のスキャ ンを行って括り，分解能は $1 \mathrm{~cm}^{-1}$ 程度であった．観測 例として $\mathrm{N}_{2} \mathrm{O}$ 吸収プロフィルに対する $\mathrm{CO}_{2}$ 吸収帯, 及 び $\mathrm{N}_{2}$ ，水蒸気による連続スペクトルの影響が示された. 又, 地上からの観測により大気中の微量成分を求める際 には, 太陽光の屈折を考慮して光路を計算する必要があ り, その理論的な解析方法についても説明された. 昭和 基地で観測されたオゾン全量と $\mathrm{NO}_{2}$ 全量の季節変動の 紹介, さらに成層圈での反応生成物のモニターなど今後 の方向を概観してまとめとされた.

大気関係の最後の講演は, 化学技術研究所加藤健次氏 により「パルス光音響法を利用した大気中の微量成分の 
計測」と題して行われた。始めに，光音響法の原理と歴 史について話された，この方法は高感度な気体分析法と して注目されて括り，レーザーを用いる励起法によりパ ルス励起法と $\mathrm{cw}$ 励起法に, 光音響セルの構造により共 鳴型と非共鳴型とに分類される，パルス励起法と cw 励 起法では前者の方が利用波長範囲は広く, 例壳ば $\mathrm{Nd}$ YAG レーザーを用いる場合, 測定対象成分は $\mathrm{CO}, \mathrm{CO}_{2}$, $\mathrm{CH}_{4}, \mathrm{SiH}_{4}, \mathrm{HCl}$ など多種類に及ぶ. 非共鳴型では空で の光吸収に起因するバックグラウンドが問題となる。一 方, 共鳴型の場合は試料ガスの出入口や空の位置を工夫 することによりフローセルとすることが可能であり，空 の吸収によるバックグラウンドを低く抑兄ることができ る. 演者の実験では共鳴モードとして軸方向モードを利 用した二重管共鳴セルを用いて招り，Nd-YAG レーザ 一に色素レーザーや非線形光学系を組合わせて 1.5 $4.5 \mu \mathrm{m}$ の波長域を測定している. $\mathrm{N}_{2}$ に希勫した $\mathrm{N}_{2} \mathrm{O}$ に関しては， $0 \sim 2.4 \mathrm{ppm}$ の濃度範囲に亘り直線性のよ い検量線が得られている。な拈，ガラスフィルターを利 用して空気中の浮遊微粒子によるシグナル低下分を測定 すれば，微量成分と共に微粒子の存在量も見ることがで き，大気環境計測上興味ある計測手法となり得ることを 示唆された.

水質計測に係る始めの講演「レーザー誘起イオン化分 光法による水中微量成分の計測」は, 公害資源研究所の 宮崎章氏によるものである. Laser Enhanced（又は， Induced) Ionization Spectrometry (以下 LEIS) は光 ガルノバ効果を利用した新しい微量分析法として注目さ れているが，これまでのところ環境分析にはあまり適用 されていない. 光ガルノバ効果の 説明の後, Nd-YAG レーザー励起・色素レーザーを光源とする演者らの装置 が紹介された．Mn を測定対象元素として，279.5 nm での信号を測定することにより，LEIS の基本特性が明 らかにされている、レーザー出力が高すぎると信号電流 は飽和する. 又, 電極電圧の増加と共にシグナルは増加 するが，シグナル・バックグラウンド比としては変化が ない. 検量線は $0.01 \sim 10 \mathrm{ppm}$ の濃度域に亘って直線性 を示すが，イオン化しやすいアルカリ元素やアルカリ土
類元素が共存するとそれらによる妨害現象が現れる。超 音波ネブライザーを用いるか，ステンレス鋼管の水冷電 極を用いると妨害は小さくなるという. DIBK をバーナ 一中に導入する場合にも水溶液と同様の信号を得ること ができる. 実際試料への応用例としては, 湖沼水や地下 水中の $\mathrm{Mn}$ の定量結果を示された. これらの結果は, イオン化しやすい元素を予め除去して測定することによ り，正確な值が得られることを示している.

最後の講演では, 国立公害研究所の古田直紀氏が「レ 一ザー励起螢光法を利用した湖沼中の污染物質の測定」 と題して, ベンゾ (a) ピレンと $\mathrm{Pb}$ の高感度分析につ いて話された．ベンゾ（a）ピレンは化石燃料の燃焼に よって生成し, 太陽光で未分解の部分が大気系から水系 一移行する. $\mathrm{Pb}$ は生活用品の中に多く用いられて和り， ベンゾ（a）ピレンと同様に人間活動による環境污染の 良い指標となる。演者らは, 污染の進んでいない摩周湖 をバックグラウンド地域として選択し, これらの濃度測 定を試みた. 分析法としては極めて高感度な方法が要求 されるため，レーザーを光源とする螢光法を採用してい る. ベンゾ (a) ピレンの測定では, 窒素レーザー励起・ 色素レーザーを光源とし, HPLCの溶出液にレーザー光 を照射して螢光 $(403 \mathrm{~nm})$ を測定した. この方法での検 出限界は $3.6 \mathrm{ppt}$ である. 一方, $\mathrm{Pb}$ の測定ではカーボ ンカップアトマイザーを用いて微少量試料を気化させ, レーザー原子螢光法による測定を行っているが, 測定環 境からの污染と思われる妨害信号のため実試料で直接分 析できるまでには至っていない、いずれの場合も，ブラ ンクレベルをいかに下げ得るかが重要で，サンプリン グ, 試料処理, 測定操作時の污染の低隇に細心の注意が 必要なことを強調された.

参加者は講師，委員を含め計34名であった．会場（定 員50名）に対してやや少なめであったが，各講演とも活 発な質疑応答が行われた，な拉，要旨集（1000円）飞多 少残部がありますので希望者は日本分光学会宛沶申出く ださい。

（化技研 久保田正明） 